\title{
Democratization and clientelism: Why are young democracies badly govemed?
}

\author{
Philip Keefer \\ Development Research Group \\ The World Bank \\ pkeefer@worldbank.org
}

The comments of Scott G ehlbach and George Clarke and participants at a seminar at the University of California, San Diego, are gratefully acknowledged. This paper and its conclusions are entirely those of the author and not those of the World Bank or its directors.

\begin{abstract}
This paper identifies and explains systematic performance differences between younger and older democracies: younger democracies are more comupt; exhibit less rule of law, lower levels of bureaucratic quality and lower secondary school enrollment; and spend more on public investment and government workers. One explanation for this is that politicians in young democracies are less credible. Keefer and Vlaicu (2004) argue that the inability of political competitors to make credible promises to citizens leads them to underprovide public goods, overprovide transfers to narrow groups of voters, and engage in excessive rent-seeking. A variety of tests suggest that this is the only theory that explains the performance of young democracies. The effect of democratic age remains large even after controlling for the possibilities that voters are less well-informed in young democracies, that young democracies have systematically different political and electoral institutions, or that young democracies exhibit more polarized societies
\end{abstract}

World Bank Policy Research Working Paper 3594, May 2005

The Policy Research W ork ing Paper Series disseminates the findings of work in progress to encourage the ex change of ideas about development issues. A n objective of the series is to get the findingsout quidkly, even if the presentations are less than fully polished. The papers carry the names of the authors and should be cited acoordingly. The findings, interpretations, and conclusions ex pressed in this paper are entirely those of the authors. They do not necessarily represent the view of the W orld Bank, its E x ecutive D irectors, or the countries they represent. Policy Research W orking Papers are available online at http:/ / econ.worldbank .org. 


\section{Democratization and clientelism: Why are young democracies badly govemed?}

\section{Philip Keefer}

Many democracies fall short of many autocracies in the provision of public services or the protection of economic or human rights. Recent contributions to the literature on democracy underline how puzzling this is. Acemoglu, et al. (2002) and others, for example, argue that universal suffrage, competitive elections and restraints on the executive branch should have a profound effect on the security of property rights. Engerman and Sokoloff (2002) argue that the expansion of the franchise should open the way to wider access to education. The evidence, though, indicates that the mere fact of elections and political checks and balances seems to guarantee little in terms of government performance, just as a large literature finds little or no relationship between democracy and economic growth.

A natural explanation for uneven democratic performance is the extreme heterogeneity of democracies. Which precise aspect of heterogeneity that matters most for government performance is still not clear, however. Indeed, even defining the dimensions of heterogeneity has proven difficult. For example, classic contributions from an older literature (e.g., Huntington 1971) argue that democracies differ significantly in the extent to which they are "politically institutionalized." This term resists easy operationalization.

The argument and evidence in this paper point to two key characteristics of democracies that explain performance disparities among democracies: their age and the ability of political competitors to make credible promises to voters. The findings below are the first to demonstrate that young democracies perform systematically differently than older democracies across a range of policy areas, from corruption controls to government 
ownership of newspapers to secondary school enrollment. The important question, however, is why this is so. The analysis below supports a new explanation: the relative inability of politicians in younger democracies to make credible promises to voters prior to elections explains the precise differences in policy choices of politicians in younger and older democracies.

Keefer and Vlaicu (2004) argue that political competitors who are unable to make credible promises to most voters will, upon taking office, underprovide public goods, overspend on transfers to narrow groups, and engage in significant rent-seeking. That is, the behavior of such politicians can be characterized as highly clientelist. However, politicians in older democracies have had greater opportunity than their counterparts in younger democracies precisely to build up policy reputations across a wide swath of the electorate. To the extent that credibility and age of democracy are related, though, younger democracies should exhibit the same behavior - under-provision of public goods, over-spending on transfers to narrow groups of citizens and high rent-seeking - predicted to emerge in countries where politicians are credible to only limited numbers of voters.

In fact, the tests below, across seven policy dimensions, reveal that younger democracies exhibit precisely this behavior. This finding is robust to numerous specifications, including political and electoral institutions, levels of voter information, ethnic fractionalization and the potential conflating influence of democratically- elected leaders who exhibit long tenures. Moreover, evidence presented below suggests that one common measure of voter information, newspaper circulation, may in fact reflect in large measure the underlying credibility of political promises to citizens. This suggests a potential alternative or complementary interpretation of studies that have linked higher newspaper circulation to such outcomes as low corruption (e.g., Adserà, et al. 2003). 


\section{The credibility of preelectoral promises and govemment performance}

The extreme heterogeneity of democratic performance is easily demonstrated. The rule of law in half of all countries exhibiting either checks and balances or competitive elections in the 1990s was the same or worse as in the median country lacking either one or the other. ${ }^{1}$ Comparisons using corruption indicators yield similar results, as do comparisons using objective indicators of performance. More than 20 percent of countries exhibiting strong checks and balances and competitive elections exhibit worse gross secondary school enrollment than the median country that does not. Lindert (2003) documents this as well, showing that "full" democracies are more likely than "elite" democrades to provide primary education. Baum and Lake (2003) find no relationship between democracy and female secondary school enrollment. The sources of this varied performance remain a continuing puzzle of growing importance, since the number of countries holding competitive elections has doubled, from 53 to 101 between 1985 and 2000, and the number exhibiting some checks and balances has risen from 62 to $112 .^{2}$

What explains the heterogeneity of democratic performance? Keefer and Vlaicu (2004) point to the credibility of pre electoral political promises. Most models assume either that all pre-electoral promises are credible to all voters, or none are (see Persson and Tabellini 2000 for a review). There are, however, scarcely any democracies in which these polar cases apply. Keefer and Vlaicu (2004) argue that when political competitors are less able to make credible promises to voters regarding public good provision and economic performance generally, they attempt either to build their credibility among smaller groups of

\footnotetext{
1 The rule of law measure is from Political Risk Services' International Country Risk G uide and the measures of checks and balances and competitive elections from the D atabase on Political Institutions. These are discussed below.

2 Based on World D evelopment Indicators PPP adjusted income per capita, and using the D atabase on Political Institutions variables E x ecutive Index of E lectoral C ompetition (E IE C) and L egislative Index of E lectoral Competition (L IE C), and Tenure of System (tensys) which are explained in more detail below.
} 
voters or to rely on patrons who, in turn, can make credible promises to clients. Either strategy influences the policy making incentives of politicians. Specifically, in low-credibility countries - where politicians are reliant on patrons or have succeeded in establishing credible relationships with a few voters - politicians focus on government policies that benefit small, targeted groups of voters, give shorter shrift to public good provision (policies that benefit voters as a whole) and are more free to engage in rent-seeking.

The effort of non-credible politicians to establish credibility with small groups of voters mirrors the well-documented relationship in the literature between patrons and clients. Scholars who have closely studied patron-client relationships in the field have found that they are personalized, on-going and reciprocal - characteristics sufficient for reputational equilibria to exist in a non-cooperative game. For example, Scott $(1972,92)$ characterizes patron- client relations in Southeast A sia as ones "in which an individual of higher socioeconomic status (patron) uses his own influence and resources to provide protection or benefits, or both, for a person of lower status (client) who, for his part, reciprocates by offering general support and assistance, including personal services, to the patron." The analysis here explains why clientelism at the social and local levels enters politics at higher levels: the credibility of patrons with respect to clients makes patrons valuable allies of political competitors. However, since patrons only value public policies that transfer benefits to their clients, political reliance on patrons also leads non-credible politicians to underprovide public goods. ${ }^{3}$

The implications for young democracies are immediate. Political competitors in younger democracies have had less chance to develop policy reputations with voters and

3 Patron preferences here are related to a generic problem in political economy. When politicians have narrow constituencies, it is easier for constituents to give credit to politicians for public services that the constituents and no one else receives than for public services that benefit all citizens and that many politidans could have had a role in providing (e.g., Mayhew 1974). 
their political parties are likely to be less well-established as vehicles for conveying credible policy stances. As a consequence, they should be more susceptible to reliance on patrons as a means to establish credible bonds with voters. This implies that the policy choices of young democracies should resemble most closely those predicted by the foregoing arguments: lower levels of public good provision, high levels of private, targeted goods, and high rent-seeking. It is this hypothesis that is the subject of the empirical analysis below.

\section{Q ualitative evidence for the pervasiveness of clientelism in young democracies}

The conclusion that political competitors in young democracies are less credible, more reliant on patrons, and more likely to focus public policy on transfers and rent-seeking than broad public good provision finds substantial implicit support in the case study literature. Various contributors in Malloy and Seligson (1987), looking at countries experiencing the transition from authoritarian to democratic government, repeatedly note the reliance of new political competitors on narrow benefits to targeted constituencies. Conaghan, for example, characterizes the parties of the young Ecuadoran democracy as fundamentally clientelist (p. 157), and Rosenberg describes political decision making in young Central American democracies as personalized and based on vertical patronage networks (p. 197). The democratic regime that succeeded the authoritarian government of G etulio Vargas in post-World War II Brazil was itself soon replaced in 1964 by the military. One of the military's purported aims in replacing this young democracy was to create the conditions for the introduction of a "clean democracy," one in which the citizenry were free of clientelist ties to political bosses and where rural voters were not controlled by country bosses (D uncan Baretta and Markoff, 53).

Sayari (1977) writes that in the early years of Turkish democracy in the 1940s, "party strategies for peasant mobilization were based largely on the recruitment of notables into 
party ranks who were then entrusted with the task of providing 'ready vote banks'. . .This strategy met a favourable resopnse from the notables since assuming the leadership post of a party's local unit meant that a notable could (a) gain additional status and prestige vis-à-vis rival notables, (b) secure new sources of outside support for members of his faction, and (c) maintain and improve his economic standing through party ties." (p. 107). These notables were the at the heads of extended clientelist networks. Sayari notes the importance to parties of providing individualized assistance: first, in navigating the bureaucracy (which are "relayed to local party leaders or deputies", 108) and, second, in the provision of public investment for rural development projects (108).

\section{Policy variables that capture differences between young and old democracies}

More systematic empirical evidence also supports the claim that politicians in younger democracies prefer transfers to narrow groups of voters, engage in greater rentseeking and underprovide public goods. Seven variables are used here to represent these different dimensions of government policy. A common measure of corruption captures rent-seeking tendencies; measures of bureaucratic quality, the rule of law, secondary school enrollment and government ownership of newspapers are employed to track government incentives to provide public goods or goods that are difficult to target to particular groups of voters; and public investment and the central government wage bill are used to capture policies that are easy for politicians to target to specific voters at the expense of voters generally. Each of these is explained in greater detail below.

\section{Measuring rent-seeking: Comuption}

Rent-seeking - the diversion of economic resources to the private requirements of political decision makers - is a key measure of government incentives to satisfy broad social interests. Measures of comuption are the most-used proxies for rent-seeking. O ne that has 
been used in a number of articles (e.g., Knack and Keefer 1995) and that, uniquely, has ample country and year coverage, is the corruption indicator from Political Risk Service's International Country Risk $\mathrm{G}$ uide. This is a subjective measure of the extent to which bribes are a significant determinant of government decision making. The measure has broad country coverage, and is available since 1986. All of the Political Risk Service variables are scaled so that higher values are "better". Hence, higher values of the corruption variable signify reductions in corruption.

\section{Measuring public or non-targeted good provision: The rule of law and the quality of bureaucracy}

The rule of law is easily seen as a consequence of government incentives to respond to broad or narrow interests in society. 4 When the rule of law prevails, the umbrella of secure property, contractual and other rights extends over all citizens. The benefits of the rule of law - faster growth, for example - similarly extend to all citizens. However, when special interests (including politicians themselves) can usethe power of government to abrogate the government's obligations to average citizens - for example, to protect the property or contractual rights of average citizens - the rule of law is weak. 5 The costs of weak rule of law are borne by citizens in general. G overnment protection of property and contract rights can therefore be seen as a policy that has public good characteristics and is not easily targeted to particular groups of citizens. The rule of law measure from Political Risk Service's International Country Risk G uide is a common measure of the extent of

\footnotetext{
4 The literature (North and Weingast 1989, Acemoglu, et al. 2002, Clague, et al. 1996) more typically argues that secure property and contractual rights are the product of political checks and balances that create institutional road blocks to government efforts to expropriate. Empirically, however, political checks and balances are weak predictors of the property rights measures used here. The divergent incentives of politicians to pursue broad public interests, the core problem in the analysis here, explains why checks and balances may not always be a strong guarantee of the security of property rights.

5 This definition of rule of law is not the only one. However, the specifics of the definition fit squarely in any definition, and are tracked by the Political Risk Services rule of law indicator.
} 
government credibility and its willingness to respect property rights of individuals (see, e.g., Knack and Keefer 1995 and A cemoglu, et al. 2002, Clague, et al. 1996).

High bureaucratic quality is another government policy with public good characteristics. Lower bureaucratic quality implies that the quality of public services offered generally by government to the average citizen is low, and that the average citizen confronts more obstacles to doing business with government. At the same time, those obstacles can always be eliminated for favored constituents of the government. Hence, bureaucratic quality is a useful indicator of the tradeoff that governments make between the pursuit of general and private interests. It can, again, be measured using the eponymous variable from Political Risk Service's International C ountry Risk G uide.

\section{Measuring public or non-targeted good provision: secondary school enrollment}

These measures of public or non-targeted good provision are subjective. The best objective measure would be one that quantified government spending on public or nontargeted goods. Unfortunately, even when we can identify categories of government spending that appear to be untargeted or dedicated to public good provision, the actual destination of these funds is often targeted. For example, education spending can be aimed at raising achievement for all children (through curriculum reforms, testing, spending on high quality teachers); or it can be targeted (by building new schools in some areas, but not in others). Cross- country budget data on education do not distinguish which.

To circumvent this difficulty, an outcome indicator, secondary school enrollment, is used below to approximate the extent to which the public component of education spending predominates. ${ }^{6}$ If politicians care relatively more about political targeting than they do about

\footnotetext{
6 Primary school enrollment could, in principle, also be used, but most countries send most of their children to primary school The coefficient of variation in the sample used here is 17.6 percent for primary school enrollment, and 50.8 percent for secondary school enrollment.
} 
providing the public good of quality education to all children, the overall quality of schooling should suffer. For example, they might locate schools or hire teachers based on criteria other than the educational payoff to those decisions. As quality falls, families should demonstrate increasing reluctance to incur the financial and opportunity costs of sending their children to secondary school and secondary school enrollment should fall.

Confidence in the validity of secondary school enrollment as a proxy for public good provision should be high if it is the case that the relationship between (targetable) spending and learning outcomes is low, if the relationship between (non-targetable) education reforms and leaming is high, and if learning outcomes are correlated with family decision to enroll children. The existing evidence is generally supportive of these relationships.

A large fraction of education spending goes to teachers. The evidence suggests little clear relationship between teacher spending and learning quality, however. First, teacher absenteeism is a notorious problem in developing country education systems and has been strongly associated with student absenteeism (see Ehrenberg, et al. 1991 on the United States; Carlson 2000 on Chile, and Harber 1989 on Nigeria). Student absenteeism is obviously an indication of low learning. It is also particularly relevant for the analysis here, where student enrollment is the variable of interest. Second, teacher quality seems more closely related to turnover of teachers and the prevalence of first year teachers (education management policies that are difficult to target) than to teacher compensation (Hanushek, et al. 2005). In sum, teacher compensation can be high, but if it is meant only to benefit teachers as a political constituency and if there is little incentive to improve education outcomes, compensation does not lead to higher teacher attendance or quality.

Additional evidence underlines the positive effects on learning of (relatively cheap) management reforms, which do not target resources to specific narrow constituences. 
Looking at four Francophone countries, Michaelowa (2001) finds that a visit by a school inspector in the past year increased scores. On the other hand, teacher absenteeism substantially reduces student performance (math/ French) for fifth graders, as did whether a teacher was a civil servant or a union member (both of which are indicators of the degree of teachers' ability to act collectively in their private interests). Moreover, these negative influences on learning more than offset the positive effects on learning associated with the presence of textbooks or the literacy of a child's parents. ${ }^{7}$

Even when the relationship between additional physical inputs and enrollment or educational achievement has been shown to be positive, the magnitude of the effect is small (see, e.g., Michaelowa 2001 and Glewwe and Jacoby 1994 on blackboards in four Francophone African countries and Ghana, respectively; and Harbison and Hanushek for a broad review). Glewwe and Jacoby (1994) only find a significant effect of the physical condition of classrooms on student testing, but condition is related to maintenance expenditures, which are precisely the types of government spending that are difficult for politicians to target (it is difficult for a politician to get credit for the repair of a door or window compared to the construction of a new school).

Taken together, this evidence shows that a focus on quality or on systems that influence outcomes across schools, neither of which is easy for politicians to target to particular constituencies, are critical to learning, but financial inputs into education are less clearly associated with learning. However, is low learning, the unobservable public good in cross- country analysis, associated with low enrollment, the variable that can be observed? Here there is less evidence, but it supports the contention that low learning environments

7 Ballou (1996) also concludes that a good academic record does little to boost an applicant's chances to be hired as a teacher in the United States and argues that this is because administrator incentives are too weakly linked to classroom performance and student achievement to persuade them to place weight on a candidate's academic success, even when this is associated wi th better classroom performance. 
drive down enrollment. One piece of evidence is reported above: teacher and student absenteeism move together. Bommier and Lambert (2000) find, in addition, that students enroll earlier in Tanzanian schools where school quality is higher. In the estimations below, therefore, gross secondary school enrollment, from W orld D evelopment Indicators, is taken as an indicator of incentives to provide public rather than private and targetable goods.

\section{Measuring public or non-targeted good provision: govemment ownership of newspapers}

The final indicator of public good provision is related to government policy towards citizen information. Since citizen information is a public good, government policies that expand or restrict citizen access to information should be influenced by the same forces that drive public good provision more generally - including the credibility of political promises. One such policy is the market share of government-owned newspapers as a fraction of the market share of the top five newspapers in a country, collected by Djankov, et al. (2003). Where the market share of government newspapers is high, citizens have less access to a diversity of information sources. Elected governments can more easily deny citizens this public good if public goods are not electorally relevant, as when political competitors cannot make credible promises to a large fraction of citizens.

It may of course also be true that elected governments with no intention of surrendering power might also foreclose citizen access to information. Such a government would pass from the category of "competitively elected", eventually, when it suppressed an election or won an election with a large super-majority, to the non-competitively elected category, creating an association, by definition, between government ownership and the continuous years of elections. In this case, however, the highest government share of the newspaper market should be found where elected leaders have the longest tenure. There is, in fact, a strongly positive relationship between the tenure of elected executives and the 
market share of government-owned newspapers. However, evidence reported below shows that the negative effect of continuous years of competitive elections on government market share is robust to controls for leader tenure.

Government-owned newspapers might also be seen as a way to increase the flow of information to citizens, for example if they are heavily subsidized and distributed below cost. There seem to be few examples where government newspapers are set up and managed for the purpose of providing unbiased information about, for example, the performance of elected officials. However, to the extent that this is true in some cases, estimates below will be biased towards rejecting the hypothesis that political credibility reduces government restrictions on citizen information.

\section{Measuring targeted govemment spending: Publicinvestment and the govemment wage bill}

Government employment and public investment or infrastructure spending are traditional ways for governments to target benefits to particular constituencies. This is straightforward to see in the case of patronage in government employment, which benefits job holders and their families. The government wage bill as a fraction of GDP, taken (like public investment) from G overnment Financial Statistics, tracks government spending on jobs and therefore offers a measure of government incentives to channel spending to targeted constituencies.

The fraction of society that benefits from a given public investment is more variable than jobs spending. Like education spending, public investment has both public good and targetable, private components. The key characteristic of public investment is not that its benefits are entirely private and targeted, but that relative to other categories of public spending, politicians can target a higher fraction of public investment undertaken every year. Most education spending, for example, is on teachers and other administrative staff. On the 
margin, politicians can influence which teachers are hired or where they are posted, but most teachers and postings are fixed from year to year. Public investment spending, on the other hand, disproportionately consists of new construction that benefits particular constituencies. Given the characteristics of public investment, politicians interested in providing narrowly targeted services to constituents should therefore be disproportionately interested in increasing public investment. In fact, as the phrase "pork barrel spending" recalls, political preferences for targetable public investment spending are well-known. Public investment spending as a fraction of GDP is therefore used here as a measure of government incentives to target public spending to specific constituencies.

\section{Explaining differences between young and old democracies}

The key concern here is to assess whether the age of democracy explains variation in policy choices across democracies. Numerous alternative hypotheses regarding policy variation must also be taken into account, however. This section describes the age of democracy variable and the other controls that enter into the econometric specifications analyzed below.

\section{Measuring the age of democracy}

The puzzle explored in this paper is why the institution of competitive elections, a defining characteristic of democracies, yields sharply different outcomes across countries. In constructing a measure of the age of democracy, therefore, the core democracy variable is based on the seven-point Legislative and Executive Indices of Electoral Competition (L IE C and E IE C ) from the D atabase on Political Institutions (Beck, et al. 2002). These variables are objective and narrow, excluding, unlike other measures of democracy, either other institutional features of countries (the presence of checks and balances) or outcomes 
(whether governments are constrained by formal institutions, or whether elections have led to the replacement of an incumbent by a challenger).

The highest score on each of these two indices (seven) is assigned to countries in which multiple parties compete in legislative and executive elections and no party receives more than 75 percent of the vote. In all of the discussion here, the continuous years of competitive elections are measured as the number of consecutive years in which a country has the highest score on both indices. From 1975 - 2000, the period under study here, the median number of years of continuous elections is eleven and the mean 27 among countries that have ever held competitive elections. ${ }^{8}$

\section{O ther control variables}

O ther geographic and demographic features of countries are likely to have a direct effect on the kinds of policies that citizens demand or that have the highest payoff for citizens. Country land area and population capture the demand for public infrastructure, since the demand for roads or the costs of providing education or ensuring the rule of law are surely different in large, sparsely populated than in small, densely populated countries. Countries with a larger fraction of young people should exhibit a greater demand for education. More young people may also increase the pressure on politicians to provide jobs and raise the costs of maintaining the rule of law, in view of the well-known association between youth and crime. There may be economies (or diseconomies) in the application of policies across a larger population; hence, total population is taken into account.

8 D PI begins in 1975. To establish the number of continuous years of democracy in 1974, the "age of democracy" variable from Clague, et al. (1996) is employed. Their methodology truncates the age of the oldest democracies, so the maximum continuous years of elections in the year 2000 in the analysis below is therefore 70, attained by 19 countries. 
Finally, the demand for, and the costs of providing, infrastructure, education or even the rule of law and integrity in government may differ substantially across rural and urban areas. These are all taken from W orld D evelopment Indicators.

The estimates of the determinants of gross secondary school enrollment have additional controls to isolate the public good aspect of school enrollment. Gross secondary school enrollment is a product of how much governments spend on education and of how they spend the money. The goods and services that governments buy may or may not be public goods. However, the way governments spend money and the oversight they give to spending outcomes are more like public goods and less targetable to specific constituencies. The education regressions therefore control for government spending on education in order to isolate the impact of years of continuous elections on the public good aspects of school policy that influence enrollment. In addition, gross primary school enrollment is controlled for, reflecting the simple fact that secondary school enrollments must drop when primary school enrollments are low; at the same time, it controls for the possibility that government spending on education might be high, but dedicated disproportionately to primary schools.

One might argue that government expenditures should be included as a control variable directly, since nearly all of the policy variables in the estimates of Tables 2 and 3 are related to government expenditure. In fact, government expenditures as a fraction of GDP are associated with significantly lower corruption and higher public investment and school enrollment. Government expenditure is nevertheless excluded from the core specifications because its inclusion reduces sample sizes by approximately 25 percent. Results, though, are robust to its inclusion. Wherever the elections variable is significant in Tables 2 and 3 below, it remains significant when controlling for government expenditure as a fraction of GDP. 
In examining the robustness of the results below, a number of other potential political characteristics of countries are also examined, including political and electoral institutions, ethnic heterogeneity, and voter information. Table 1 presents a summary of all of the variables used here. Note that each continuous episode of competitive elections constitutes an observation. All variables are therefore averaged over the duration of the episode.

Table 1: Summary statistics

\begin{tabular}{|c|c|c|c|c|}
\hline Variable & $\mathbf{N}$ & Mean & median & std dev. \\
\hline Rule of law & 101 & 6.187 & 6.167 & 2.48 \\
\hline $\begin{array}{l}\text { Share of government-owned newspapers/ } \\
\text { market share of top five newspapers }\end{array}$ & 75 & .16 & 0 & .32 \\
\hline Corruption in government & 100 & 5.89 & 5 & 2.25 \\
\hline Bureaucratic quality & 101 & 5.816 & 5.39 & 2.61 \\
\hline Gross seco ndary school enrollment & 121 & 62.885 & 65.32 & 31.87 \\
\hline Public investment/ GDP & 86 & 0.039 & 0.032 & 0.027 \\
\hline Gov't. wages/ GD P & 91 & 0.061 & 0.055 & .035 \\
\hline Average continuous years of competitive elections & 137 & 13.35 & 5.5 & 17.65 \\
\hline Ethnolinguistic polarization & 128 & 0.561 & 0.038 & 0.72 \\
\hline Newpaper circulation per 1000 inhabitants & 118 & 119.66 & 71.99 & 131.2 \\
\hline Majoritarian (1) or non-majoritarian & 137 & 0.328 & 0 & 0.47 \\
\hline $\begin{array}{l}\text { Presidential (2), Semi-presidential (1), } \\
\text { or Parliamentary (0) }\end{array}$ & 137 & 1.096 & 1.692308 & 0.95 \\
\hline Percent population young & 133 & 0.336 & 0.353 & 0.1 \\
\hline Total population (10 millions) & 135 & 33600000 & 8330978 & 104000000 \\
\hline Percent population rural & 134 & 0.487 & 0.49275 & 0.22 \\
\hline Land (millions $\mathrm{km}^{2}$ ) & 133 & 825394 & 143000 & 2190413 \\
\hline Total government expenditures/ GD P & 91 & 0.286 & 0.28 & 0.11 \\
\hline Primary school enrollment & 123 & 99.47 & 100.7 & 17.59 \\
\hline Total education expenditures/ GDP & 115 & 0.034 & 0.032 & 0.02 \\
\hline
\end{tabular}

N.B. O bservations are episodes of continuous competitive elections. Variables are the sum of the 
yearly observations divided by the number of years the episode lasts in the sample (a maximum of 26 years, since the data run from 1975 - 2000).

\section{Estimation strategy}

The ideal test of the hypothesis that the credibility of preelectoral political promises influences policy would be:

(1) $\quad$ Policy choiœ $\left.\aleph_{i}=\beta_{0}+\beta_{1}(\text { credibility of political competitors })_{i}\right)+\mathbf{X}_{\mathrm{i}} \mathrm{B}+\mathrm{e}_{\mathrm{i}}$. where i indexes the democratic episode under observation. Two problems make this approach difficult and are the focus of this section. First, credibility is unobservable.

Second, credibility is likely to be a function of some of the elements in $\mathbf{X}$, giving rise to multicollinearity.

The previous discussion suggests a close relationship between the number of continuous years of competitive elections and credibility, suggesting the elections variable as a natural proxy for unobserved credibility. In particular, because credibility can emerge from reputation, and reputation is a possible product of repeated experience with politicians, one might expect a positive association between the continuous years of competitive elections and the ability of politicians to make credible pre-electoral promises. Given this, we can express credibility as a function of the elections variable,

(2) $\quad$ Credibility $\mathrm{y}_{\mathrm{i}}=\alpha_{0}+\alpha_{1}$ (ontinuous years of competitive elections) $+u_{\mathrm{i}}$.

Substituting (2) into (1) yields,

(3) Policy choiø $\aleph_{\mathrm{i}}=\beta_{0}+\beta_{1}\left(\alpha_{0}+\alpha_{1}\right.$ (continuous years of ompetitive elections) $+\mathrm{u}_{\mathrm{i}}$. $)+\mathbf{X}_{\mathrm{i}} \mathrm{B}+\mathrm{e}_{\mathrm{i}}$.

\section{Attenuation bias and multicollinearity}

It is always the case that the use of a proxy variable introduces attenuation bias in the estimate of the coefficient of the proxied variable. That is, because the years of continuous elections captures the effects of credibility imperfectly, with error $u$, the estimate of $\beta_{1}$ is biased downwards. The attenuation bias naturally increases the less close is the connection 
between credibility and the elections variable (the greater is $\sigma_{u}^{2}$ ). It is less often observed, however, that attenuation bias worsens in the presence of multicollinearity. This is a particular issue here because of strong associations between credibility and some of the elements in $\mathbf{X}$.

To see this effect, assume that there is only one element in $\mathbf{X}=\mathrm{x}_{2}$, set credibility $=\mathrm{x}_{1}$, suppress constant terms, and let $\left(\sum x_{2, i}^{2} \sum x_{1, i}^{2}-\left(\sum x_{1, i} x_{2, i}\right)^{2}\right)=Q$. Then the estimate of $\beta_{1}$ is given by

$\mathrm{b}_{1}=\frac{\beta_{1}}{\frac{1}{\alpha Q}\left[\sum x_{2, i}^{2} \sum x_{1, i}^{2}-\left(\sum x_{1, i}\right)^{2}\left(\sum x_{2, i}\right)^{2}\right]+\frac{\sigma_{u}^{2}}{\alpha Q}\left(\sum x_{2, i}^{2}-\left(\sum x_{2, i}\right)^{2}\right)}$.

Recall that the correlation coefficient between $\mathrm{x}_{2}$ and credibility $=\mathrm{x}_{1}$ is equal to $\frac{\sum x_{1, i} x_{2, i}}{\sum x_{2, i} \sum x_{1, i}}$, and note that it is inversely related to $Q$. It is evident, then, that the greater is the correlation between the two credibility and other determinants of policy, the larger is $\frac{\sigma_{u}^{2}}{\alpha Q}$ and the greater is attenuation bias (which is zero when $\sigma_{u}^{2}$ is zero). ${ }^{9}$

The policy determinant $x_{2}$ may influence credibility directly or, through its influence on the continuous years of competitive elections, indirectly. Effects are similar in either case, but the second case is easiest to demonstrate. Assume, as is plausible, that the number of continuous years of competitive elections is determined by a process like $z_{i}=\gamma_{1} w_{i}+\gamma_{2} x_{2, i}+v_{i}$, where $\mathrm{w}$ is an exogenous and unobserved variable unrelated to policy outcomes that influences the elections variable. But then the process determining

\footnotetext{
${ }^{9}$ See Annex 1 for the full derivation.
} 
credibility, equation (2), can be rewritten as $x_{1, i}=\alpha\left(\gamma_{1} w_{i}+\gamma_{2} x_{2, i}+v_{i}\right)+u_{i}$. The correlation between $\mathrm{x}_{1}=$ credibility and $\mathrm{x}_{2}$ is given by $\alpha \gamma_{2}$. That is, the more that $\mathrm{x}_{2}$ influences the continuous years of elections, the greater is the downward bias in the estimation of the effect of credibility on policy outcomes when using the elections proxy.

Three of the control variables included below in $\mathbf{X}$ are likely also to influence credibility: the fraction of the population that is rural, the fraction that is young, and income per capita. Not only do they have direct effects on policy, they also are likely to have direct and indirect effects (through the continuous years of competitive elections) on credibility. Rural voters are more isolated and strategies to improve political credibility with respect to these voters, such as personal contact with the voters, are more costly per voter. This directly inhibits the development of credibility. Younger voters have less experience with political actors. Experience is key to the formation of reputation and credibility, so it is more costly for politicians to convey credible promises to them. Income per capita is also likely to have strong effects on credibility. Politicians can invest resources in making their appeals to individual constituents credible, promising private transfers, jobs or assistance in times of distress; or they can invest in making their appeals to large groups credible, building the credibility of their promises to provide public goods that will benefit large groups in the most cost-effective way. The poorer is a country, the more likely is the first strategy to be the most cost-effective way to achieve political support (as Dixit and Londregan 1996 observe).

There is substantial evidence for indirect effects. The years of continuous elections is negatively correlated with the percent of the population that is rural $(\rho=-0.51)$ and the percent that is young $(\rho=-.50)$. It is positively correlated with income 
per capita ( $\rho=.71){ }^{10}$ To the extent that rural, young or poorer populations are less wellserved by democracies, they are also less likely to be more passive in the face of efforts to overthrow democracy. For example, if rural voters are more likely to be the captives of "patrons", they would be less likely to benefit from political competition under democracy and less opposed to threats to democracy.

To address attenuation bias and multicollinearity, two strategies are employed. The first is to use instrumental variables. These are a well-known solution to attenuation bias due to measurement error (e.g., if credibility were directly measured, but with error), where the instrument is correlated with "true" credibility and uncorrelated with the error term in the observed credibility measure. In the case of proxy variables, as here, the valid instrument must be correlated with continuous years of elections, but not with the error term u.

Multicollinearity of the type suggested here disrupts the efficacy of the IV approach, however. The predicted value of the continuous years of elections, from the first stage of the IV estimation, is a function of the instruments for the continuous years of elections and the controls $\mathbf{X}$ from the second stage of the equation. However, credibility and the continuous years of elections are partially determined by $\mathbf{X}$. Consequently, the instrument will only be valid (significant in the first stage regression of the instrument on continuous years of elections) if it has substantial explanatory power above and beyond that of the variables in $\mathbf{X}$. To the extent that these variables are significant determinants of the elections variable or of credibility, the instruments will fail. In fact, as we might expect, the

\footnotetext{
10 The connection between poverty or agricultural dominance and democratic instability is well-established (Przeworski, et al. 2000, Boix and Stokes 2003, Boix 2001). These relationships are typically explained in terms of class conflict, the marginal returns to capital in poor countries and wealth redistribution (see Boix and Stokes for a summary). Unlike this explanation, the argument here takes into account that key aspects of political competition (e.g., whether voters are informed or not, or politicians are credible or not) vary systematically among democracies and that class-based parties and conflict over wealth distribution are rare in most young and poor democracies.
} 
instruments that are widely- used in the cross-country institutions literature are rarely significant in the first stage regression in the presence of the variables in $\mathbf{X}$.

The second strategy used here is therefore to investigate the effects of dropping the collinear variables. The usual criterion to judge the reasonableness of this step is whether the resulting increase in precision is large relative to the introduction of an unknown bias due to the omission of these variables. Here, because the collinear variables create a significant source of downward bias in the OLS regressions, a stronger case than usual can be made that the tradeoff is worthwhile. In the estimates below, therefore, estimates of (2) are therefore undertaken with and without those variables in $\mathbf{X}$ for which there is a strong a priori case that they influence both credibility and policy choice. The change in coefficient values after dropping these variables is consistent with the a priori argument that the presence of the variables $\mathbf{X}$ exacerbate the attenuation bias in the OLS regressions and spuriously undermine the validity of instruments in the IV regressions.

\section{Endogeneity}

The IV estimations below address both measurement error and possible endogeneity concerns. These concerns are easy to exaggerate, however. One might argue, for example, that causality is reversed and that policy choice itself drives regime duration. That is, governments that choose bad policies trigger greater opposition than those that do not. This argument alone is not enough to establish that reverse causation drives the results we observe. First, bad policy should lead citizens to prefer challengers to incumbents, but not necessarily to prefer autocracy to democracy. O ne needs, in addition, an argument that suggests why bad policy should lead to regime change. The credibility arguments here provide precisely such an argument: the less credible are political competitors in a democracy, the less acountable they are and the more indifferent citizens should be between 
elected and unelected political leaders. But one cannot use this argument to assert that the results below in Table 2 are spurious since this argument and the credibility arguments advanced earlier to interpret Table 2 are entirely consistent with each other.

A different model of reverse causation might assert that an omitted variable is a determinant of policy, though not of regime duration, but it is policy that determines the number of continuous years of competitive elections. What might that omitted variable be, however? Policy is the product of government incentives; the latent credibility variable is one that explains the pattern of policies observed across democracies. Again, then, to the extent that credibility drives policy choice, it is difficult to argue that reverse causation explains the results observed in equation (2). The literature suggests other possible latent influences. All of these are examined below, however, and found not to explain the difference between democracies of different ages. Finally, in any case, the IV strategy used here also addresses potential endogeneity concerns.

\section{Results}

Public investment, the wage bill of the central government, the rule of law, and bureaucratic quality are all approximately one standard deviation higher and secondary school enrollment one standard deviation lower in countries where competitive elections have been held for fewer than the median number of continuous years. The market share of government-owned newspapers is 32 percent of the market share of the top five newspapers in countries with fewer than the median years of continuous competitive elections and close to zero in countries with more years.

These bivariate associations emerge strongly in the regressions in Table 2. For each of the seven policy variables, Table 2 presents two sets of estimates of equation (2). The first is a simple regression controlling for the land area of the country and total population 
and, in the equation for secondary school enrollment, controlling as well for education spending and primary school enrollment. The second set of estimates controls, in addition, for the three variables likely to have strong effects on government credibility: the percent of the population that is young or rural, and income per capita.

The pattern of election coefficients across the different policies is exactly consistent with the credibility explanation: rent-seeking falls (recalling that the corruption is worst when the corruption variable is lowest) and government provision of public goods (the rule of law, bureaucratic qu ality, the absence of government newspapers and secondary school enrollment) rises the more continuous years of competitive elections that countries have experienced. In contrast, government provision of targeted goods - through public investment or public employment - falls. The earlier argument suggests that the introduction of the variables percent population that is young or rural and income per capita would lead to a drop in the estimate of the elections coefficient. The second regression in each of the regression pairs, demonstrates that this is the case: in the presence of these three variables, the estimates of the elections coefficient, though still highly significant, drop substantially in magnitude. ${ }^{11}$

The magnitude of the election or credibility effect is in most cases large. For example, in the more parsimonious specifications in Table 2, a one standard deviation increase in the continuous years of competitive elections (approximately 20 years) is associated with a reduction in corruption of more than onehalf a standard deviation, increases the rule of law by onethird of a standard deviation and bureaucratic quality by

\footnotetext{
11 If the three control variables are determinants of political credibility, their signs should be consistent with the credibility arguments made earlier. In all those cases where the estimated coefficients of the variables are significant, their signs are consistent with the credibility hypothesis: corruption is lower, public good provision is higher, and fewer targeted goods are provided the greater is income; corruption and the government wage bill are higher and some public good provision is lower the younger is the population.
} 
more than onehalf a standard deviation, and secondary school enrollment by onefourth of a standard deviation. ${ }^{12}$

12 Clague, et al. (1996) and Treisman (2000) find that measures of the age of democracy are positively related to the rule of law and corruption but do not explain the finding. The results here and below extend their findings in three ways. First, the results here reflect tests of specific explanations of why age of democracy should matter for political incentives to maintain the rule of law or to seek rents - years of election is not simply an additional control variable. Second, the estimates here are based on an objective measure of democracy that emphasizes the specific institution of voting rather than broader characterizations of democracy. Finally, the results here are found to be robust to a number of alternative explanations. 
Table 2: Effect of the persistence of competitive elections

\begin{tabular}{|c|c|c|c|c|c|c|c|c|c|c|c|c|c|c|}
\hline \multirow{2}{*}{$\begin{array}{l}\text { D ependent variable: } \\
\text { Continuous years of } \\
\text { competitive elections }\end{array}$} & \multicolumn{2}{|c|}{$\begin{array}{l}\text { Corruption in } \\
\text { Government }\end{array}$} & \multicolumn{2}{|c|}{ Rule of law } & \multicolumn{2}{|c|}{$\begin{array}{l}\text { Bureaucratic } \\
\text { quality }\end{array}$} & \multicolumn{2}{|c|}{$\begin{array}{c}\text { Market Share, } \\
\text { Gov't-owned } \\
\text { newspapers }\end{array}$} & \multicolumn{2}{|c|}{$\begin{array}{c}\text { Gross } \\
\text { secondary } \\
\text { school } \\
\text { enrollment } \\
\end{array}$} & \multicolumn{2}{|c|}{$\begin{array}{c}\text { Central gov't. } \\
\text { wage bill/ GD P }\end{array}$} & \multicolumn{2}{|c|}{$\begin{array}{c}\text { Public } \\
\text { investment/ GDP }\end{array}$} \\
\hline & $\begin{array}{l}.088 \\
(.00)\end{array}$ & $\begin{array}{l}.051 \\
(.00)\end{array}$ & $\begin{array}{l}.083 \\
(.00)\end{array}$ & $\begin{array}{l}.02 \\
(.03)\end{array}$ & $\begin{array}{l}.10 \\
(.00)\end{array}$ & $\begin{array}{l}.03 \\
(.00)\end{array}$ & $\begin{array}{l}-.005 \\
(.00)\end{array}$ & $\begin{array}{l}.002 \\
(.07)\end{array}$ & $\begin{array}{l}.93 \\
(.00)\end{array}$ & $\begin{array}{l}.24 \\
(.012)\end{array}$ & $\begin{array}{l}-.0005 \\
(.002)\end{array}$ & $\begin{array}{l}-.0005 \\
(.02)\end{array}$ & $\begin{array}{l}-.0003 \\
(.00)\end{array}$ & $\begin{array}{l}-.00006 \\
(.59)\end{array}$ \\
\hline $\begin{array}{l}\text { Total population (10 } \\
\text { millions) }\end{array}$ & $\begin{array}{l}-.14 \\
(.003)\end{array}$ & $\begin{array}{l}-.13 \\
(.01)\end{array}$ & $\begin{array}{l}-.17 \\
(.01)\end{array}$ & $\begin{array}{l}-.12 \\
(.08)\end{array}$ & $\begin{array}{l}.12 \\
(.18)\end{array}$ & $\begin{array}{l}.21 \\
(.00)\end{array}$ & $\begin{array}{l}-.34 \\
(.02)\end{array}$ & $\begin{array}{l}-.49 \\
(.002)\end{array}$ & $\begin{array}{l}-3.5 \\
(.00)\end{array}$ & $\begin{array}{l}-.64 \\
(.38)\end{array}$ & $\begin{array}{l}-.006 \\
(.00)\end{array}$ & $\begin{array}{l}-.007 \\
(.001)\end{array}$ & $\begin{array}{l}-.0003 \\
(.001)\end{array}$ & $\begin{array}{l}-.0005 \\
(.00)\end{array}$ \\
\hline Land (million $\mathrm{km}^{2}$ ) & $\begin{array}{l}-.01 \\
(.81)\end{array}$ & $\begin{array}{l}-.14 \\
(.82)\end{array}$ & $\begin{array}{l}.29 \\
(.39)\end{array}$ & $\begin{array}{l}.06 \\
(.91)\end{array}$ & $\begin{array}{l}.31 \\
(.52)\end{array}$ & $\begin{array}{l}.31 \\
(.61)\end{array}$ & $\begin{array}{l}-.03 \\
(.65)\end{array}$ & $\begin{array}{l}-.01 \\
(.91)\end{array}$ & $\begin{array}{l}-1.9 \\
(.86)\end{array}$ & $\begin{array}{l}-5.26 \\
(.23)\end{array}$ & $\begin{array}{l}-.03 \\
(.00)\end{array}$ & $\begin{array}{l}-.03 \\
(.03)\end{array}$ & $\begin{array}{l}-.002 \\
(.00)\end{array}$ & $\begin{array}{l}-.0002 \\
(.19)\end{array}$ \\
\hline $\begin{array}{l}\text { GDP/ capita (real, } \\
\text { PPP-adjusted, } \\
\text { thousands) }\end{array}$ & & $\begin{array}{l}.083 \\
(.16)\end{array}$ & & $\begin{array}{l}.15 \\
(.00)\end{array}$ & & $\begin{array}{l}.28 \\
(.00)\end{array}$ & & $\begin{array}{l}.005 \\
(.47)\end{array}$ & & $\begin{array}{l}.84 \\
(.06)\end{array}$ & & $\begin{array}{l}.02 \\
(.13)\end{array}$ & & $\begin{array}{l}.001 \\
(.19)\end{array}$ \\
\hline $\begin{array}{l}\text { Percent population } \\
\text { young }\end{array}$ & & $\begin{array}{l}-7.2 \\
(.012)\end{array}$ & & $\begin{array}{l}-11.9 \\
(.00)\end{array}$ & & $\begin{array}{l}-2.12 \\
(.45)\end{array}$ & & $\begin{array}{l}1.72 \\
(.003)\end{array}$ & & $\begin{array}{l}-192.4 \\
(.00)\end{array}$ & & $\begin{array}{l}.13 \\
(.02)\end{array}$ & & $\begin{array}{l}.02 \\
(.54)\end{array}$ \\
\hline $\begin{array}{l}\text { Percent population } \\
\text { rural }\end{array}$ & & $\begin{array}{l}1.11 \\
(.24)\end{array}$ & & $\begin{array}{l}1.25 \\
(.23)\end{array}$ & & $\begin{array}{l}1.27 \\
(.24)\end{array}$ & & $\begin{array}{l}.15 \\
(.64)\end{array}$ & & $\begin{array}{l}-12.89 \\
(.14)\end{array}$ & & $\begin{array}{l}.025 \\
(.32)\end{array}$ & & $\begin{array}{l}.03 \\
(.05)\end{array}$ \\
\hline $\begin{array}{l}\text { Primary school } \\
\text { enrollment }\end{array}$ & & & & & & & & & $\begin{array}{l}.44 \\
(.03)\end{array}$ & $\begin{array}{l}.26 \\
(.004)\end{array}$ & & & & \\
\hline $\begin{array}{l}\text { Total education } \\
\text { expenditures/ GD P }\end{array}$ & & & & & & & & & $\begin{array}{l}-91.6 \\
(.53)\end{array}$ & $\begin{array}{l}139.5 \\
(.11)\end{array}$ & & & & \\
\hline $\mathrm{R}^{2}$ & .57 & .66 & .43 & .72 & .55 & .73 & .15 & .40 & .40 & .86 & .22 & .30 & .17 & .31 \\
\hline $\mathrm{N}$ & 99 & 97 & 100 & 98 & 100 & 98 & 74 & 74 & 107 & 107 & 90 & 90 & 86 & 85 \\
\hline
\end{tabular}

N.B. p-values in parentheses. Each observation is the average across a country-regime, beginning in the first year a country has competitive elections (or 1975) and ending in the last year that a country has competitive elections (or 2000). Robust standard errors are reported, clustered by country so that multiple country-regimes from the same country are not treated as independent observations. All regressions include a constant (not reported). Instruments in the IV regression marked with $*$ do not satisfy the exclusion assumption. 
Table 3 reports the IV estimates of the regressions in Table 2 using two instruments, latitude and British colonial heritage. These estimates are meant to address both possible endogeneity issues and measurement error due to the use of the elections proxy variable. With respect to endogeneity, neither instrument is plausibly rel ated to policy choices from 1975 to 2000, the years over which data are available for the estimations. With respect to measurement error, neither seems plausibly related to the measurement error $u$ that emerges from using the elections variable as a proxy for credibility. At the same time, latitude (or geographic location more generally) and colonial experience are likely to capture unobserved factors that might influence whether countries become democratic and how long they are able to remain democratic. ${ }^{13}$

Recalling the earlier discussion, the strong relationship between years of continuous elections, credibility and the controls for the two population variables and income per capita mean that no instruments significantly predict the elections variable in the presence of these controls. Table 3 results are based on the more parsimonious specifications in Table 2 . In every case, the coefficient estimate of the elections variable is larger in the IV estimates in Table 3 than in the corresponding estimates in Table 2. The use of instruments therefore seems to reduce attenuation bias due to measurement error, suggesting that measurement error - downward bias - rather than endogeneity-driven upward bias is the main concern arising from the OLS regressions of Table 2.

\footnotetext{
13 These are two of several variables that are standard in the literature linking cross country outcomes to institutional variables. Others (such as settler mortality, fraction of English speakers, years since independence) fail as instruments because they are insignificant determinants of the continuous years of competitive elections.
} 
Table 3: Effect of the persistence of competitive elections - T wo-stage least squares

\begin{tabular}{|c|c|c|c|c|c|c|c|}
\hline D ependent variable: & $\begin{array}{l}\text { Corruption in } \\
\text { Govemment }\end{array}$ & $\begin{array}{l}\text { Rule of } \\
\text { law }\end{array}$ & $\begin{array}{c}\text { Bureaucratic } \\
\text { Q uality }\end{array}$ & $\begin{array}{l}\text { Market Share, } \\
\text { Gov't-owned } \\
\text { newspapers }\end{array}$ & $\begin{array}{l}\text { Gross secondary } \\
\text { school enrollment }\end{array}$ & $\begin{array}{c}\text { Central gov't. } \\
\text { wage bill/ GDP }\end{array}$ & $\begin{array}{c}\text { Public } \\
\text { investment/ GDP }\end{array}$ \\
\hline $\begin{array}{l}\text { Continuous years of } \\
\text { competitive } \\
\text { elections }\end{array}$ & $\begin{array}{l}.11 \\
(.00)\end{array}$ & $\begin{array}{l}.12 \\
(.00)\end{array}$ & $\begin{array}{l}.12 \\
(.000)\end{array}$ & $\begin{array}{l}-.008 \\
(.03)\end{array}$ & $\begin{array}{l}1.778 \\
(.00)\end{array}$ & $\begin{array}{l}-.0006 \\
(.05)\end{array}$ & $\begin{array}{l}-.0005 \\
(.01)\end{array}$ \\
\hline $\begin{array}{l}\text { Total population } \\
\text { (10 millions) }\end{array}$ & $\begin{array}{l}-.1 .3 \\
(.015)\end{array}$ & $\begin{array}{l}-1.3 \\
(.08)\end{array}$ & $\begin{array}{l}.014 \\
(.20)\end{array}$ & $\begin{array}{l}-.4 \\
(.023)\end{array}$ & $\begin{array}{l}-1.1 \\
(.30)\end{array}$ & $\begin{array}{l}-.006 \\
(.000)\end{array}$ & $\begin{array}{l}-.003 \\
(.002)\end{array}$ \\
\hline Land (millions $\mathrm{km}^{2}$ ) & $\begin{array}{l}-.025 \\
(.80)\end{array}$ & $\begin{array}{l}.053 \\
(.61)\end{array}$ & $\begin{array}{l}-.02 \\
(.82)\end{array}$ & $\begin{array}{l}-.03 \\
(.86)\end{array}$ & $\begin{array}{l}-2.9 \\
(.02)\end{array}$ & $\begin{array}{l}-.004 \\
(.001)\end{array}$ & $\begin{array}{l}-.03 \\
(.01)\end{array}$ \\
\hline $\begin{array}{l}\text { Primary school } \\
\text { enrollment }\end{array}$ & & & & & $\begin{array}{l}.49 \\
(.002)\end{array}$ & & \\
\hline $\begin{array}{l}\text { Total education } \\
\text { expenditures/ GDP }\end{array}$ & & & & & $\begin{array}{l}63.6 \\
(.73)\end{array}$ & & \\
\hline $\mathrm{R}^{2}$ & .94 & .92 & .92 & .34 & .88 & .83 & .73 \\
\hline $\mathrm{N}$ & 95 & 96 & 96 & 65 & 96 & 79 & 78 \\
\hline $\begin{array}{l}\text { F- test on instruments } \\
\text { in first stage }\end{array}$ & 12.92 & 12.35 & 12.35 & 10.32 & 14.62 & 15.51 & 15.48 \\
\hline $\begin{array}{l}\text { H ansen'sJ -test of } \\
\text { hypothesis that } \\
\text { instruments can be } \\
\text { ex duded from second } \\
\text { stage } \\
\text { (p-value) }\end{array}$ & .08 & .37 & .57 & .91 & .93 & .002 & .006 \\
\hline
\end{tabular}


The validity of the IV estimates depends on whether the instruments predict the elections variable and whether they can be legitimately excluded from the set of $\mathbf{X}$ variables thought to determine policy. With regard to the first, the F-test roundly rejects the null hypothesis that the instruments provide no explanatory power in the first stage equation; the F-statistic is in every case quite large. In four of the seven cases, the J-test also rejects the hypothesis that the instruments should not be excluded from the second stage regression. The IV results of Table 3 therefore provide strong evidence in four of the seven cases that downward bias in the credibility/ elections coefficient due to measurement error is the primary problem in the estimates of Table 2 and that signifcant results are not due to endogeneity driven by reverse causation or omitted variables.

In the other three cases, the IV results are suggestive that endogeneity is not an issue, though not conclusive. However, the analyses in the sections that follow introduce a series of additional political and other variables into the estimations. The main results do not change, providing further evidence that Table 2 results are not driven by the omission of key variables.

\section{Other influences on political incentives: polarization and political institutions}

The results in Tables 2 and 3 provide substantial evidence of a relationship between the continuous years of competitive elections and policy outcomes. This relationship is exactly consistent with what one would expect if the underlying problem of younger democracies is the unobserved difficulty that political competitors have in making credible promises. However, younger and older democracies differ for other reasons. It is possible that these other reasons, ranging from political institutions and social polarization to citizen 
information, are driving the results obtained so far. ${ }^{14}$ In this and the following sections, two arguments are made. First, as a theoretical matter, only credibility differences between young and older democracies are predicted to have the policy effects observed here. Second, empirically, the evidence suggests that these other political and social variables do not account for the effects of the elections variable on policy outcomes.

One of these variables is polarization. Voter polarization might increase or decrease public good spending and corruption, however. Effects are contingent on the number of polarized groups and electoral institutions. Voters who are highly polarized on ideological dimensions might give very little weight to the policy promises or performance of candidates, allowing ideologically preferred candidates to increase rent-seeking and reduce provision of public services without suffering an electoral penalty, predictions identical to the credibility model outlined earlier. Altenatively, as Persson and Tabellini (2000, chapter 8) show, polarization might lead to reduced rent-seeking, lower public good provision and higher targeted good provision. ${ }^{15}$ These predictions stand in sharp contrast to the credibility model.

In the analysis below, ethnolinguistic fractionalization (the probability that two randomly selected people are not from the same ethnic or linguistic group) is transformed to reflect more closely the concept of social polarization. As in Keefer and Knack (2002), the

\footnotetext{
14 See Keefer and Khemani (2003) for a review of these findings.

15 They assu me three groups of voters. Voters from one group prefer on average one party independent of the policies advocated by the party; voters from a second group prefer the other party; voters from the third are on average indifferent. By construction, the pol arization of the first two groups falls as within-group heterogeneity increases. As polarization falls (heterogeneity increases) relative to the middle group of swing voters, governments loser fewer votes from the more extreme groups when they transfer resources from public good provision to targeted goods benefiting only the swing group. Transfers therefore rise, but rent-seeking falls, since increased competition for the support of swing voters forces politicians to give up rent-seeking. With other preference distributions, however, other outcomes are possible. For example, if 51 percent of voters have a strong ideological predisposition towards one party, and 49 percent are strongly disposed against the party, the 51 percent will be reluctant to remove "their" party even if rent-seeking is rampant. In majoritarian electoral systems, polarization has no effect, since competitors care only about swing voters under all ideological distributions.
} 
highest values of social polarization are assigned to countries in which individuals have approximately a 50 percent chance of encountering someone from the same ethnolinguistic group and the lowest values when they have either a very high chance or very low chance of encountering someone from the same ethnolinguistic group. The theory suggests that it is this middle range of fractionalization in which societies are likely to be most polarized, since two large and evenly matched groups are more likely to generate conflict than many small groups or one large group. Ethnic polarization, so defined, is about one half a standard deviation higher in countries with fewer than the median number of years of continuous elections.

The institutional literature also offers powerful explanations for variations in performance across democracies. Persson and Tabellini (2000) examine the effect of changes in numerous electoral and political institutions on government spending decisions, particularly the provision of public goods, transfers to narrow constituencies, and rentseeking. Of greatest interest here, they show that electoral institutions - whether elections are first past the post or proportional, whether district magnitudes are large or small - have a significant impact on these decisions. However, the direction of the institutional effect depends heavily on the specification of the model and on whether one cares about local public goods or national public goods. ${ }^{16}$

Electoral rules and political systems are also predicted in the literature to have systematic effects on government policy making, though not necessarily in directions that explain the outcomes here. Majoritarian voting systems might encourage an intense focus

\footnotetext{
16 If pre-electoral promises are credible, swing districts receive disproportionate attention in majoritarian systems. Targeted transfers are therefore higher and public good provision lower, as in the low credibility model, but unlike the low credibility case, rents are also lower under majoritarian systems. If promises are not credible, and politicians can do nothing to increase their credibility, transfers play no role in voter decision making and they go to zero in all electoral systems, proportional or majoritarian. Rents, though, are higher under majoritarian electoral rules.
} 
on transfers to narrow constituencies (swing districts), which would also reduce corruption; presidential systems might encourage low corruption, but also low public good spending (see Persson and Tabellini 2000). Using information from the D PI, countries are coded as majoritarian if they have plurality electoral rules and the median district magnitude is less than three, following Persson, Tabellini and Trebbi (2003). The political systems of countries whether they are parliamentary or presidential - is determined based on the system variable from the D PI. Countries with more years of continuous elections are approximately 50 percent more likely to be parliamentary democracies with proportional representation electoral rules. Majoritarian rules by themselves are not, however, correlated with the continuous years of competitive elections. 
Table 4: Altemative explanations for the perfomance of young democracies

\begin{tabular}{|c|c|c|c|c|c|c|c|}
\hline & $\begin{array}{l}\text { Corruption in } \\
\text { government }\end{array}$ & Rule of law & $\begin{array}{l}\text { B ureaucratic } \\
\text { quality }\end{array}$ & $\begin{array}{l}\text { Market share of } \\
\text { government } \\
\text { newspapers }\end{array}$ & $\begin{array}{c}\text { Gross } \\
\text { secondary } \\
\text { school } \\
\text { enrollment }\end{array}$ & $\begin{array}{l}\text { Government } \\
\text { wages/ G D P }\end{array}$ & $\begin{array}{c}\text { Public } \\
\text { investment/GD } \\
\mathrm{P}\end{array}$ \\
\hline $\begin{array}{l}\text { Persistence of } \\
\text { competitive elections }\end{array}$ & $\begin{array}{l}.07 \\
(.000)\end{array}$ & $\begin{array}{l}.04 \\
(.000)\end{array}$ & $\begin{array}{l}.07 \\
(.000)\end{array}$ & $\begin{array}{l}-.002 \\
(.12)\end{array}$ & $\begin{array}{l}.72 \\
(.000)\end{array}$ & $\begin{array}{l}-.0005 \\
(.01)\end{array}$ & $\begin{array}{l}-.0003 \\
(.02)\end{array}$ \\
\hline $\begin{array}{l}\text { Ethnolinguistic } \\
\text { polarization }\end{array}$ & $\begin{array}{l}.37 \\
(.10)\end{array}$ & $\begin{array}{l}.93 \\
(.001)\end{array}$ & $\begin{array}{l}.34 \\
(.29)\end{array}$ & $\begin{array}{l}-.10 \\
(.021)\end{array}$ & $\begin{array}{l}2.6 \\
(.52)\end{array}$ & $\begin{array}{l}-.006 \\
(.29)\end{array}$ & $\begin{array}{c}-.01 \\
(.004)\end{array}$ \\
\hline $\begin{array}{l}\text { Majoritarian (1) or non- } \\
\text { majoritarian (0) }\end{array}$ & $\begin{array}{l}-.58 \\
(.10)\end{array}$ & $\begin{array}{l}.49 \\
(.30)\end{array}$ & $\begin{array}{l}-.06 \\
(.88)\end{array}$ & $\begin{array}{l}.14 \\
(.20)\end{array}$ & $\begin{array}{l}-9.9 \\
(.12)\end{array}$ & $\begin{array}{l}.003 \\
(.76)\end{array}$ & $\begin{array}{l}-.0008 \\
(.92)\end{array}$ \\
\hline $\begin{array}{l}\text { Parliamentary (2), Semi- } \\
\text { presidential (1), or } \\
\text { Presidential (0). }\end{array}$ & $\begin{array}{l}.25 \\
(.21)\end{array}$ & $\begin{array}{l}.88 \\
(.001)\end{array}$ & $\begin{array}{c}.81 \\
(.002)\end{array}$ & $\begin{array}{l}-.08 \\
(.09)\end{array}$ & $\begin{array}{c}7.3 \\
(.028)\end{array}$ & $\begin{array}{l}.01 \\
(.02)\end{array}$ & $\begin{array}{l}.007 \\
(.035)\end{array}$ \\
\hline $\mathrm{R}^{2}$ & .60 & .54 & .60 & .30 & .46 & .31 & .29 \\
\hline $\mathrm{N}$ & 88 & 91 & 91 & 70 & 102 & 88 & 84 \\
\hline $\begin{array}{l}\text { Persistence of } \\
\text { competitive elections }\end{array}$ & $\begin{array}{l}.06 \\
(.000)\end{array}$ & $\begin{array}{l}.03 \\
(.002)\end{array}$ & $\begin{array}{l}.06 \\
(.000)\end{array}$ & & $\begin{array}{l}.27 \\
(.05)\end{array}$ & $\begin{array}{l}-.0001 \\
(.55)\end{array}$ & $\begin{array}{c}-.0001 \\
(.34)\end{array}$ \\
\hline Newspaper circulation & $\begin{array}{l}.006 \\
(.000) \\
\end{array}$ & $\begin{array}{l}.009 \\
(.000)\end{array}$ & $\begin{array}{l}.006 \\
(.000)\end{array}$ & & $\begin{array}{l}.14 \\
(.000) \\
\end{array}$ & $\begin{array}{c}-.0001 \\
(.03) \\
\end{array}$ & $\begin{array}{c}-.00004 \\
(.009) \\
\end{array}$ \\
\hline $\mathrm{R}^{2}$ & .64 & .57 & .62 & & .60 & .24 & .18 \\
\hline $\mathrm{N}$ & 96 & 96 & 96 & & 103 & 85 & 80 \\
\hline
\end{tabular}

N.B. p-values in parentheses. Control variables are the same as in Table 2, but, along with constants, are not reported. Each observation is the average across a country-regime beginning in the first year a country has competitive elections (or 1975) and ending in the last year that a country has competitive elections (or 2000). Robust standard errors are reported, clustered by country so that multiple country-regimes from the same country are not treated as independent observations. 
Table 4 regressions show that none of these variables accounts for the difference in performance between younger and older democracies. The table reports two sets of regressions. Eah uses as a base the more parsimonious of each pair of specifications in Table 2. The first set of regressions in Table 4 controls, simultaneously, for polarization, whether countries have majoritarian electoral systems, and whether they have parliamentary political systems. The second set, discussed in the section below, evaluates the effect of newspaper circulation (voter information). If the estimates of the election coefficients in Table 2 are driven by the omission of any of these variables, the elections coefficient in Table 4 should be small and insignificant.

In fact, although they in general differ systematically between younger and older democracies, ethno-linguistic polarization and political and electoral institutions do not explain the pattern of policies preferred by countries with fewer years of continuous elections. The elections variable remains significant, with approximately the same magnitude as in Table 2, even after inclusion of the polarization and institutional variables. Ethnic polarization is associated with less government involvement in newspapers and public investment, but also less gross secondary school enrollment, this last consistent with findings on public good spending in Alesina, Baqir and Easterly (1999). Majoritarian electoral laws and parliamentary systems are associated with higher corruption (recalling that higher values of the corruption variable imply more integrity and less corruption), in contrast to Persson, Tabellini and Trebbi (2003) but majoritarian systems are associated as well with larger secondary school enrollments. Parliamentary, non-majoritarian systems also exhibit less government involvement in newspapers. 


\section{Other influences on political incentives: voter information}

Limited voter information about politician types or actions also creates distortions in the policy making process. This section explores whether voter information, rather than credibility, explains the elections results in Table 2. The test turns out to be far from straightforward, however, since a strong argument can be made that the standard proxy for citizen information, newspaper circulation, is itself heavily influenced by government policies that are determined by the credibility of government promises, such as government ownership of newspapers.

Grossman and Helpman (1996) predict that the larger the fraction of voters who are uninformed about the preferred policy stance of politicians, the greater are political incentives to collect resources from special interests in return for favors in order to "inform" these voters. Since younger democracies are likely to have fewer informed voters, models in this vein predict that young democracies are more likely to exhibit policies benefiting narrow rather than broad interests. Besley and Burgess focus on the tradeoff between providing private transfers to voters and rent-seeking by politicians. Their analysis predicts that politicians will shirk less (engage in less rent-seeking) and channel more state resources to citizens in the form of transfers when media exposure and voter turnout are greater. These analyses do not address whether better-informed citizens would encourage politicians to channel resources to public good provision at the expense of private goods, however. That is, it is not yet clear how voter information influences the incentives of politicians to appeal to narrow versus broad segments of society.

Newspaper circulation is the most-used proxy for voter information, one that is relevant in the discussion of the behavior of young democracies. It is three times greater in countries where elections have occurred for more than 19 continuous years than in countries 
where they have occurred for fewer. Besley and Burgess find that greater circulation of vernacular newspapers leads governments to make larger transfers to citizens affected by food shortages. ${ }^{17}$ Adserá, et al. (2003) and others also find that in cross- country comparisons, newspaper ciralation per 1000 population, from W orld D evelopment Indicators, is significantly associated with lower corruption. Taken together, the literature provides support for the notion that voter information - rather than political credibility - might explain the policy performance of young democracies.

Newspaper circulation appears to be highly vulnerable to government policy intervention. Using data from Djankov, et al. (2003), one finds that a 40 percent increase (one standard deviation) in the market share of state owned newspapers as a fraction of the market share of the top five newspapers is associated with a reduction in newspaper circulation by 0.4 standard deviations. It is likely that newspaper circulation may itself be a proxy for both unobserved political credibility and unobserved citizen information, making it difficult to interpret the estimated effects of newspaper circulation on policy.

Despite this ambiguity, the lower set of regressions in Table 4 adds newspaper circulation to the basic regression specification of Table 2 , across all policy areas but the market share of government newspapers. The elections variable remains significant in all but two cases when newspaper circulation is included, despite the likely association of newspaper circulation and the credibility of political actors. Further supporting the argument that newspaper circulation is related to credibility, newspaper circulation is itself associated with lower corruption, higher public good provision (rule of law, bureaucratic

\footnotetext{
17 Strömberg considers a similar information problem, but assumes that credible pre-electoral promises can be made, and shows that households with radios were more likely to receive transfers from a particular US government program during the G reat D epression.
} 
quality, secondary school enrollment), and lower transfers to targeted groups (public investment and government employment).

\section{0 ther influences on political incentives: leader effects}

Although the results in Table 2 are robust to a variety of specifications, including controls for alternative political determinants of pol icy, the somewhat generous definition of competitive elections used here (multiple parties competing with no party receiving more than 75 percent of the vote) might encompass countries in which a single leader has survived in office for considerable periods of time. The elections variable might therefore conflate the years of continuous competitive elections with leader effects - the years that an individual leader has been in office. These leader effects can be significant, though their predicted direction is ambiguous. This section documents that the results on the continuous years of competitive elections in Tables 2 and 3 are robust to controlling for the average tenure of the executive in each democratic period.

Przeworski, et al. (2000) argue that elected leaders cannot be assumed to be democratically accountable until a democratic transition from one party to another has occurred. The definition of democracy used here, which counts democratic duration from the very first election, may therefore conflate the effects of credibility with the proven ability of older democracies to expel entrenched leaders. On the other hand, Clague, et al. (1996) and others have emphasized that long-surviving autocrats are associated with more secure property rights. It is not clear whether this logic carries through to the experience of longsurviving elected executives. To the extent that it does, the elections variable in Tables 2 and 3 may actually be capturing the policy effects of leaders who expect to remain in office longer. 
The omission of the average tenure of leaders may also generate other biases. For example, efforts by elected leaders to suppress political competition through vote fraud, the unbridled use of public funds for political purposes, or through outright legal restrictions on potential challengers, are difficult to observe but potentially influence both the elections variable and policy outcomes. Annex 2 provides evidence of close links between the years of competitive elections and the average tenure of elected leaders. Controls for the average tenure of leaders should effectively capture much of these unobserved anti-democratic political tactics.

Although there are numerous arguments to suggest that unobserved leader effects might bias the elections variable used above, none of these are borne out in practice. A variable controlling for the tenure of individual leaders, the average years in office of the chief executive over the democratic episode in question (from the D atabase of Political Institutions) was included in all of the specifications in Tables 2 and 3 . In every case, the estimated coefficient of the elections variable was highly robust. These results are not reported since, for most of the policies under consideration, the average years in office of the executive is insignificant. ${ }^{18}$

\section{Conclusion}

The number of continuous years of competitive elections has a significant impact on seven policy areas widely identified as key to economic development. Only one explanation for this finds support in the foregoing tests: where political competitors are less able to make credible promises to voters, policies are distorted in the same fashion that we observe when we compare policy choices across younger and older democracies. Patron-client relationships in society are transported to the political realm with greater facility in such an

18 Y ears in office significantly increases the market share of government newspapers, as well as the rule of law and bureaucratic quality in two specifications, but is otherwise insignificant. 
environment, generating high transfers, high rent-seeking, and low levels of public good provision.

This argument ties together elements of a diverse body of research examining clientelism, the performance of young democracies and the importance of democratic institutions for key public policy outcomes. Huntington (1971) has famously argued that political systems are unstable when political participation advances more rapidly than political institutionalization. These broad relationships are not easy to test, or even to define. For example, Huntington suggests that systems are more highly institutionalized when they are "more adaptable, complex, coherent and autonomous" (1971, p. 315). Shefter (1994) uses a more concrete notion of institutionalization - whether a well-functioning state apparatus exists - and argues that when elections precede the development of such an apparatus, clientelism (manifested as patronage) is more likely to emerge. These analyses do not address the question of the conditions under which such an apparatus emerges, why they should change voter and politician behavior, nor what specific policy distortions we should expect to se in less institutionalized states. The logic in this paper helps to fill in these gaps by documenting the relationships among political credibility, clientelism, the continuous years of competitive elections and government policy decisions.

The view of institutionalization developed here helps to explain other puzzles thrown up by the literature. Clague, et al. (1996), for example, show that the age of democracies has a significant impact on the security of property rights, but do not explain why leaders of younger democracies would be systematically less willing to defend the security of property rights. ${ }^{19}$ Treisman(2000) and Adserà (2003) both find that democracy,

\footnotetext{
19 Their argument is one of reverse causation: democracies fail when democratic leaders do not protect property rights. The empirical evidence in Table 3 suggests that there is also a substantial effect in the other direction, from the age of democracy to the protection of property rights.
} 
per se, has no robust effect on corruption. Treisman finds that only long-lived democracies exhibit less corruption than other countries. In addition to expanding on such findings, this paper offers another explanation for them.

Further work is needed to clarify the effects of political credibility on government decision making, however. For example, how does political credibility affect the relationship between political and electoral institutions and government decisions? Further evidence is needed, as well, that tests the credibility hypothesis directly and that investigates the complex relationship among credibility, the persistence of democracy, and such variables as income and the age of the population and its urban-rural distribution. 


\section{Annex 1: Multicollinearity exacerbates attenuation bias}

To see that multicollinearity can exacerbate downward bias due to the attenuation effect, assume that policy, $\mathrm{y}$ is influenced only by credibility, $\mathrm{x}_{1}$, which is unobserved, and a second observable variable, $\mathrm{x}_{2}$. Assume that credibility is only a function of the observable continuous years of competitive elections, $z$, and that constants are suppressed. That is:

1) $\quad y_{i}=\beta_{1} x_{1, i}+\beta_{2} x_{2, i}+\varepsilon_{i}$

2) $\quad x_{1, i}=\alpha z_{i}+u_{i}$

so that we estimate

$$
y_{i}=\beta_{1}\left(\alpha z_{i}+u_{i}\right)+\beta_{2} x_{2, i}+\varepsilon_{i}=\beta_{1} \alpha z_{i}+\beta_{2} x_{2, i}+\beta_{1} u_{i}+\varepsilon_{i}
$$

The estimated coefficients of $\beta_{1}=b_{1}$ and $\beta_{2}=b_{2}$ are given by $[b]=\left[S_{x x}\right]^{-1}\left[S_{x y}\right]$,

where

$$
\left[S_{x x}\right]^{-1}=\frac{1}{\frac{1}{\alpha^{2}} \sum\left(x_{1, i}-u_{i}\right)^{2} \sum x_{2, i}^{2}-\left(\frac{1}{\alpha} \sum\left(x_{1, i}-u_{i}\right) \sum x_{2, i}\right)^{2}}\left[\begin{array}{cc}
\sum x_{2, i}^{2} & -\frac{1}{\alpha} \sum\left(x_{1, i}-u_{i}\right) x_{2, i} \\
-\frac{1}{\alpha} \sum\left(x_{1, i}-u_{i}\right) x_{2, i} & \frac{1}{\alpha^{2}} \sum\left(x_{1, i}-u_{i}\right)^{2}
\end{array}\right]
$$

and

$$
\begin{gathered}
{\left[S_{x y}\right]=\left[\begin{array}{c}
\frac{1}{\alpha} \sum\left(x_{1, i}-u_{i}\right)\left(\beta_{1} x_{1, i}+\beta_{2} x_{2, i}+\varepsilon_{i}\right) \\
\sum x_{2, i}\left(\beta_{1} x_{1, i}+\beta_{2} x_{2, i}+\varepsilon_{i}\right)
\end{array}\right] .} \\
\text { Setting } \frac{1}{\alpha^{2}} \sum\left(x_{1, i}-u_{i}\right)^{2} \sum x_{2, i}^{2}-\left(\frac{1}{\alpha} \sum\left(x_{1, i}-u_{i}\right) \sum x_{2, i}\right)^{2}=D \text { and multiplying, } \\
\text { we get }[b]=\left[S_{x x}\right]^{-1}\left[S_{x y}\right]= \\
\frac{1}{D}\left[\begin{array}{c}
\frac{1}{\alpha} \sum x_{2, i}^{2} \sum\left(x_{1, i}-u_{i}\right)\left(\beta_{1} x_{1, i}+\beta_{2} x_{2, i}+\varepsilon_{i}\right)-\frac{1}{\alpha} \sum\left(x_{1, i}-u_{i}\right) x_{2, i} \sum x_{2, i}\left(\beta_{1} x_{1, i}+\beta_{2} x_{2, i}+\varepsilon_{i}\right) \\
-\frac{1}{\alpha^{2}} \sum\left(x_{1, i}-u_{i}\right) x_{2, i} \sum\left(x_{1, i}-u_{i}\right)\left(\beta_{1} x_{1, i}+\beta_{2} x_{2, i}+\varepsilon_{i}\right)+\frac{1}{\alpha^{2}} \sum\left(x_{1, i}-u_{i}\right)^{2} \sum x_{2, i}\left(\beta_{1} x_{1, i}+\beta_{2} x_{2, i}+\varepsilon_{i}\right)
\end{array}\right]
\end{gathered}
$$


The first row of this expression is the solution for $b_{1}$. Multiplying through, noting that $\mathrm{x}_{1}, \mathrm{x}_{2}, \mathrm{u}$ and $\varepsilon$ are independent of each other, and simplifying, we get $\mathrm{b}_{1}=$

$\frac{1}{D}\left[\frac{1}{\alpha} \sum x_{2, i}^{2} \sum x_{1, i}\left(\beta_{1} x_{1, i}+\beta_{2} x_{2, i}\right)-\frac{1}{\alpha} \sum x_{1, i} x_{2, i} \sum x_{2, i}\left(\beta_{1} x_{1, i}+\beta_{2} x_{2, i}\right)\right]$

$=\frac{1}{D} \beta_{1} \frac{1}{\alpha}\left(\sum x_{2, i}^{2} \sum x_{1, i}^{2}-\left(\sum x_{1, i} x_{2, i}\right)^{2}\right)$

Simplifying D, and dividing numerator and denominator

$\operatorname{by}\left(\sum x_{2, i}^{2} \sum x_{1, i}^{2}-\left(\sum x_{1, i} x_{2, i}\right)^{2}\right)=Q$, yields

$$
\mathrm{b}_{1}=\frac{\beta_{1}}{\frac{1}{\alpha Q}\left[\sum x_{2, i}^{2} \sum x_{1, i}^{2}-\left(\sum x_{1, i}\right)^{2}\left(\sum x_{2, i}\right)^{2}\right]+\frac{\sigma_{u}^{2}}{\alpha Q}\left(\sum x_{2, i}^{2}-\left(\sum x_{2, i}\right)^{2}\right)}
$$

As usual, attenuation arises because the continuous years of elections is not a perfect indicator of credibility, captured in (4) by the term $\sigma_{u}^{2}$. Where $\sigma_{u}^{2}$ is zero, there is no attenuation bias. The larger is the effect of the variance of the error in equation (3), the greater is the attenuation effect. This in turn means that the smaller is $Q$, the larger is the attenuation effect. It is straightforward to see that the higher the correlation between $\mathrm{x}_{1}$ and $\mathrm{x}_{2}$, the smaller is $\mathrm{Q}$.

Note that the correlation between the two variables is $\frac{\sum x_{1, i} x_{2, i}}{\sum x_{2, i} \sum x_{1, i}}$. The larger is the numerator, the higher is the correlation, the higher is the second term in Q, $\left(\sum x_{1, i} x_{2, i}\right)^{2}$, and the lower is $Q$. Similarly, the lower is the denominator, the higher is the correlation, the lower is the first term in $Q$, and again, the lower is $Q$. That is, the more highly correlated is unobserved credibility with the second determinant of policy outcomes, 
the more that the coefficient estimate of the effect of credibility, derived from the use of the proxy variable continuous years of elections, is biased downwards.

This correlation could be high for a number of reasons. One that is straightforward to identify and is evident in the data is the following. The continuous years of elections in a country is not entirely exogenous. In fact, it is likely to be influenced by the same variables, such as $\mathrm{x}_{2}$, that influence policy. That is, it is likely to emerge from a process something like: 5) $\quad z_{i}=\gamma_{1} w_{i}+\gamma_{2} x_{2}+v_{i}$ We can then rewrite (2) as $x_{1, i}=\alpha\left(\gamma_{1} w_{i}+\gamma_{2} x_{2}+v_{i}\right)+u_{i}$ and note immediately that the correlation between credibility and $\mathrm{x}_{2}$ is given by $\alpha \gamma_{2}$. The more that $\mathrm{x}_{2}$ influences the continuous years of elections, the greater is the downward bias in the estimation of the effect of credibility on policy outcomes when using the elections proxy. 


\section{Annex 2: Leader tenure and the duration of democracy}

It is clear that elected leaders who succesfully pursue unobservable, undemocratic efforts to drive out competitors would be less accountable and, therefore, more likely to engage in corruption and less inclined to provide broad-based public goods. Substantial evidence also indicates that leader tenure truncates the continuous periods of competitive elections. If elected leaders are successful in suppressing competition, they eventually win more than 75 percent of the vote and drop out of the "competitive elections" category that defines the elections variable. Alternatively, leaders who suppress electoral competition encourage non-electoral competition, increasing the likelihood that unelected leaders will replace them. Again, the country is dropped from the "competitive elections" category.

In the D PI, there are 36 episodes in which countries leave the most competitive electoral category. In all 36 cases, the average tenure of incumbents prior to the change in electoral competitiveness is higher than average: 7.3 years, compared to 4.3 years for all country-years during periods of continuous competitive elections. In addition, the majority party controlled 66 percent of the seats in the legislature on average, compared to 58 percent, on average, among all countries in the "most competitive" category.

In fourteen of the 36 cases, the government remained in power, continued to hold somewhat less competitive elections (in which multiple parties competed, but the government party received more than 75 percent of the vote) and simply accumulated a more dominant political position. In these cases, the government majority in the legislature rose to 77 percent, on average. In 13 of the 22 cases in which the incumbent lost power, on the other hand, the new government took control extrainstitutionally and not even sham elections were held. (Following the DPI coding of L IE C and E IE C, the group of 19 countries fell from scores of 7 on L IE C or E IE C to 6, while the 13 countries that 
abandoned elections fell from 7 to 2.) This evolution is precisely what one would expect control of government to change in countries in which the incumbency advantage is large.

There are numerous examples of the following kind that illustrate the more statistical findings. The former President of Perú, Alberto Fujimori, entered office having gathered approximately 25 percent of the first round votes in 1990. It is well-known that he enjoyed increasing public support, even after dissolving the legislature and firing most judges in 1992, and that he captured about 65 percent of the vote in 1995, against the former $\mathrm{G}$ eneral Secretary of the United Nations, Javier Pérez de Cuellar. Less known is that, once in office, Fujimori was aggressive about personally inaugurating small projeccts around the country. and nearly immediately, he began to assiduously cultivated voters who had scant knowledge of him by personally inaugurating small, narrowly targeted public works projects in their villages, using such well-financed programs rolled by the President's O ffice, such as FONCODES. 


\section{References}

A cemoglu, Daron, James A. Robinson and Simon Johnson (2002). " Reversal of Fortune: Geography and Institutions in the Making of the Modern World." Q uarterly Journal of E conomics. 117: 1231 - 1294 (November).

Adserà, Alícia, Carlos Boix and Mark Payne (2003). “Ae you being served? Political accountability and governmental performance." Journal of L aw, E conomics and Organization 19:445-490 (O ctober).

Alesina, Alberto, Reza Baqir and William Easterly (1999). "Public Goods and Ethnic Divisions". The Q uarterly Journal of E conomics, 1243-1284 (November)

Ballou, D ale (1996). “D o Public Schools Hire the Best Applicants?” The Q uarterly Journal of E onomics 111:1, 97 - 133 (February).

Baum, Matthew and David Lake (2003). "The Political Economy of G rowth: Democracy and Human Capital." A mericn Journal of Political Scienœ47:2, 333-347 (April).

Beck, Thorsten, George Clarke, Alberto G roff, Philip Keefer and Patrick Walsh (2001). "New Tools in Comparative Political Economy: The Database of Political Institutions." W orld Bank E œnomic Review, 15(1): 165-176.

Besley, T. and R. Burgess (2003). "The Political Economy of G overnment Responsiveness: Theory and Evidence from India". Q uarterly Journal of E conomics, Forthcoming

Boix, Carles (2001). "D emocracy, D evelopment and the Public Sector." A merican Journal of Political Science 45:1, 1-17.

and Susan Stokes (2003). “Endogenous D emocratization.” W orld Politics 55:4, 517549.

Bommier, Antoine and Sylvie Lambert (2000). "Education demand and age at school enrollment in Tanzania." The Journal of $\mathrm{H}$ uman Resources. 35:1, 177-203 (Winter). 
Carlson, Beverly A. (2000). "Achieving Educational Quality: What Schools Teach Us -

Learning from Chile's P900 Primary Schools." Serie D esarrollo Productivo No. 64, CEPAL, Santiago, Chile (January).

Christopher Clague, Philip Keefer, Stephen Knack and Mancur Olson (1996). "Property and

Contract Rights under Democracy and Dictatorship.” The Journal of E œnomic G rowth 1:2, 243-276 (June).

Comment [NB1] INSTRUCTIONS FOR FILLING PRRFORM

Cox, Gary W. (1987). The E fficient Secret: The Cabinet and the development of political parties in

V ictorian E ngland. New Y ork: Cambridge University Press.

Cox, Gary W. and Mathew McCubbins (1986). "Electoral Politics as a Redistributive

Game." Journal of Politics. 48: 370 - 389.

Dixit, Avinash and John Londregan (1996). "The Determinants of Success of Special

Interests in Redistributive Politics." Journal of Politics 58: 1132-1155.

Djankov, Simeon, Caralee McLiesh, Tatiana Nenova and Andrei Shleifer (2003). Journal of L aw and E conomics 46:2 (October).

D uncan Baretta, Silvio R. and John Markoff (1987). “Brazil’s A bertura: A transition from what to what?" In Seligson and Malloy, eds., 43 - 66.

Ehrenberg, Ronald G., Randy A. Ehrenberg, D aniel I. Rees, Eric L. Ehrenberg (1991).

"School District Leave Policies, Teacher Absenteeism, and Student Achievement." Journal of H uman Resourœes 26:1, 72-105 (Winter).

Engerman, Stanley L. and Kenneth L. Sokoloff (2001). "The Evolution of Suffrage Institutions in the New World." NBER Working Paper No. 8512 (O ctober). (2002). " Factor endowments, inequality and paths of development among New World economies." NBER Working Paper No. 9259 (O ctober).

Ferejohn, John (1986). "Incumbent performance and electoral control.” Public C hoiœ 50: 5- 
26.

Glewwe, Paul and Hanan Jacoby (1994). "Student Achievement and Schooling Choice in Low-Income Countries: Evidence from G hana." The Journal of H uman Resouroes 29:3, 843-864.

Grossman, G ene M. and Elhanan Helpman (1996). "Electoral Competition and Special Interest Politics." The Review of E conomic Studies. 63: 2, 265-286.

Hanushek, Eric A. (1996). "Measuring Investment in Education." Journal of E conomic Perspectives 10:1, 930 (Fall). , John Kain, Daniel O’Brien and Steven Rifkin (2005). “The Market for Teacher Quality.” NBER Working Paper W11154 (February).

Harber, Clive (1989). Politics in A frican E ducation. London: Macmillan.

Huntington, Samuel P. (1971). "The Change to Change: Modernization, Development and Politics." Comparative Politics. 3:3, 283-322 (April).

Keefer, Philip and Stephen Knack (2002). "Boondoggles and expropriation: rent-seeking and policy distortion when property rights are insecure." World Bank Policy Research Working Paper 2910 (O ctober). (2002). "Polarization, Property Rights and the Links between Inequality and Growth.”. Public C hoice. 111:1-2, 127-154 (March).

Kitschelt, Herbert (2003). "The D emise of Clientelism in Affluent Capitalist Democracies: A political-economic explanation." Mimeo. D uke University D epartment of Political Scienœ.

Knack, Stephen and Philip Keefer (1995). "Institutions and Economic Performance: CrossCountry Tests Using Alternative Institutional Measures." Economics and Politics 7:3, 207-228 (November). 
Libecap, Gary D. and Ronald N. Johnson (1994). The F ederal Civil Service System and the Problem of Bureaucracy: The E conomics and Politics of Institutional Change National Bureau of Economic Research Series on Long-term Factors in Economic D evelopment. Chicago and London: University of Chicago Press.

Lindert, Peter H. (2003). "Voice and G rowth: Was Churchill Right?” Journal of E œnomic H istory. 63:2, 315 - 350 (June).

Londregan, John B. and Keith T. Poole (1990). "Poverty, the Coup Trap, and the Seizure of Executive Power.” W orld Politics 42:2 (January), 151-183.

Malloy, James M. and Mitchell A. Seligson, eds. (1987). A uthoritarians and D emocrats: Regime Transition in L atin A meric. Pittsburgh: University of Pittsburg Press.

Mayhew, D avid (1974). C ongress: The E lectoral Connection. New Haven: Y Yle University Press.

Michaelowa, Katharina (2001). "Primary Education Q uality in Francophone Sub-Saharan Africa: D eterminants of Leaming Achievement and Efficiency Considerations." W orld D evelopment 29:10, 1699-1716.

North, D ouglass C. and Barry R. Weingast (1989). "Constitutions and Commitment: The Evolution of Institutions Governing Public Choice in Seventeenth-Century England." Journal of E conomic H istory. 49:4, 803-32 (D ecember).

Persson, Torsten and Guido Tabellini (2000). Political E conomics: E x plaining Public Policy. Cambridge, MA: The MIT Press. and Francesco Trebbi (2003). "Electoral Rules and Corruption." Journal of the E uropean E onomic A ssociation. 1:4 958-89 (June).

Przeworski, Adam, Michael E. Alvarez, Jose Antonio Cheibub and Fernando Limongi (2000). D emocracy and D evelopment: Political Institutions and W ell-being in the W orld, 1950 
- 1990. (New York: Cambridge University Press).

Rosenberg, Mark (1987). "Political Obstacles to D emocracy in Central America." In Malloy and Seligson, eds, p. 193 - 218.

Sanmartín, Marta (2001). "Linearity of the retum to education and self-selection." A pplied E conomics 33 (103 - 142).

Scott, James C. (1972). "Patron-Client Politics and Political Change in Southeast Asia." A merican Political Scienœ Review 66: 1, 91 - 113 (March).

Shefter, Martin (1994). Political Parties and the State. The A merican H istorical E x perience Princeton: Princeton University Press.

Stromberg, David (2001) "Radio's Impact on New Deal Spending", mimeo, Princeton University.

Treisman, D aniel (2000). "The Causes of Corruption: A Cross-National Study." Journal of Public E conomics. 76:3, 225-56 (July-September). 